\title{
The Incentives Balance Test in the EU Microsoft Case: A More "Economics-Based" Approach?
}

\author{
November, 2005 \\ Preliminary draft \\ (please, do not quote without permission - \\ comments are welcome)
}

Simonetta Vezzoso*

\begin{abstract}
Microsoft's claim that it had an objective justification for its refusal to supply interoperability information covered by intellectual property rights was dismissed by the EU Commission. To substantiate this, the Commission applied a newly framed incentives balance test and concluded that the need to protect Microsoft's incentives to innovate, under the specific circumstances of the case, could not objectively justify the undertaking's refusal to license. On the contrary, Microsoft's incentives to innovate were most likely to increase if it were required to license its interoperability information to competitors. This new balancing test is very controversial, both from the economic and legal perspective. It can also be questioned whether the balancing test to justification has been correctly applied in the case at issue. However, the paper purports to show that, for future discussion under the expected policy debate on a more "economics-based" approach to Article 82 of the EU Treaty, valuable insights can be gained from a careful scrutiny of the incentives balance test. In particular, the test helps realizing that a dynamic competition approach on the abuse of dominant position should devote considerable efforts to better understand the working of innovation processes at different industry layers. Moreover, that at least equally challenging is the identification of the appropriate competition remedies in industries characterized by, on the one side, Schumpeterian modes of innovation, and, on the other, strenuous stasis forces like network effects.
\end{abstract}

\section{Introduction}

The next ${ }^{1}$ step in the modernisation process of EU competition law that started almost a decade ago will possibly imply a revision of the Commission's policy on the abuse of a dominant position under Article 82 of the EC Treaty. In a way similar to the reform of Article 81 and merger control policy, this policy reorientation will most likely support a more "economics-based" approach to the abuse of dominant position. ${ }^{2}$ Amongst the issues that are

\footnotetext{
* Law Department, Faculty of Economics, Trento (Italy), svezzoso@economia.unitn.it.

${ }^{1}$ Currently under discussion is a refined economic approach to State Aid, see the State Aid Action Plan, under http://europa.eu.int/comm/competition/state_aid/others/action_plan/saap_en.pdf.

${ }^{2}$ In these terms is the suggestion put forth by the Economic Advisory Group for Competition Policy (EAGCP) in a report commissioned by the Chief Economist of EU Commission's DG Competition, to be visioned at http://europa.eu.int/comm/competition/publications/studies/eagcp_july_21_05.pdf. This view is supported by a number of commentators, see e.g. B.Sher, The Last of the Steam Powered Trains - Modernising Article 82, (5)
} 
possibly going to attract considerable attention under the expected policy debate is the doctrine on the unilateral refusal to license intellectual property rights. ${ }^{3}$ Under EC competition law, a refusal to license by a dominant undertaking does not amount as such to abusive behaviour. However, the refusal to grant a licence by an undertaking dominating a given market can be abusive under Article 82 if additional elements are stated. ${ }^{4}$ An early source of judicial authority for the identification of those elements is the judgement of the European Court of Justice in Radio Telefis Eireann (RTE) and Independent Televion Publications Ltd (ITP) $v$ Commission ${ }^{5}$, more commonly known as Magill, followed by other relevant pronouncements $^{6}$, last of which is IMS-Health. ${ }^{7}$

A substantial issue in the EU Microsoft case $^{8}$ also originated at the intersection between competition and intellectual property law. According to the Commission, Microsoft infringed Article 82 by refusing to disclose interface information, notwithstanding the various intellectual property rights Microsoft claimed on it. ${ }^{9}$ For our purposes, the reasoning of the Commission on the objective justification for the refusal to release this information is particularly noteworthy. In the Commission's opinion, the need to protect one's intellectual property was not as such a justification for the denial to supply information covered by it. In order to be objectively justified, the refusal to disclose information protected by intellectual property rights should pass a sort of incentives balancing test. The undertaking's denial to supply cannot claim to be objectively justified under Article 82 if the negative impact of a compulsory licence on the dominant firm's incentives to innovate are outweighed by its positive impact on the innovation level in the entire industry. ${ }^{10}$ After examination of the circumstances of the case, the Commission concluded that there was a serious risk that Microsoft would have succeeded in eliminating all effective competition in the work group server operating system market and that this would have produced "a significant negative effect on its incentives to innovate as regards its client PC and work group server operating system products." ${ }^{11}$ Therefore, on balance, the possible negative impact of the order to supply

ECLR, p. 243 et seq.; J.Vickers, Abuse of Market Power, 115(504) Economic Journal (2005), at 244 et seq. Draft guidelines on the application of Article 82 should be released by the end of 2005 .

${ }^{3}$ The unilateral refusal to license falls under the more general category of "refusal to supply", comprising refusal by the dominant undertaking to supply tangible and intangible assets, as well as to provide access to physical infrastructure.

${ }^{4}$ Case 238/87, AB Volvo v Erik Veng [1988] ECR 6211.

${ }^{5}$ Joined cases C-241/91 P and 242/91 P [1995] ECR I-743. The European Cort of Justice made first explicit in Magill some "exceptional circumstances" in which a refusal to license may be an abuse pursuant to Article 82 EC. First, the intellectual property at issue was indispensable for the production of a new type of product for which there was a demonstrable and unsatisfied consumer demand; second, the intellectual property owner, by his refusal, was eliminating all competition on a secondary market; and, third, there was no objective justification for the refusal (paras. 54-56).

${ }^{6}$ Case T-504/93, Tierce Ladbroke v Commission [1997] ECR II-923, Case C7/97, Oscar Bronner v Mediaprint [1999] ECR I-2981.

${ }^{7}$ Case C-418/01, IMS Health GmbH \& Co. OHG v NDC Health GmbH \&Co. KG. [2004] ECR I-5039.

${ }^{8} \mathrm{COMP} / \mathrm{C}-3 / 37.792$.

${ }^{9}$ Id. para. 546.

${ }^{10}$ Id. para. 783

${ }^{11}$ Id. para 725 
information on Microsoft's incentives to innovate was outweighed by its positive impact on the level of innovation of the whole industry.

If upheld by the European Courts ${ }^{12}$, the incentives balance test for the objective legitimacy of a denial to grant a licence could possibly stand for the most notable contribution of the Microsoft case to the refusal to license doctrine in EU competition law. Especially in light of the expected policy reform of Article 82, the question arises whether this test is conceptually appropriate, economically founded, and capable of providing an administrable legal tool. Manifestly, the newly introduced test is highly controversial, both from the economic and legal perspective. ${ }^{13}$ It is also questionable whether the balancing test to justification has been correctly applied in the Microsoft case itself. ${ }^{14}$ Despite the ultimate dismissal of this test, either by the judiciary and/or on theoretical and practical grounds, this paper purports to show that valuable topics and insights for future discussion under the approaching policy debate can be gained from its careful examination. As a starting point this paper revises the incentives balance test as framed in the Microsoft decision (Section 2); in the following it deals with some relevant issues pertaining to the working of innovation processes this test touches on (Sections 3, 4 and 5). Section 6 concludes by summing up some open questions from the viewpoint of a pro-innovation competition policy.

\section{The Objective Justification for Refusal to License in Microsoft Europe}

According to the EU Commission, Microsoft infringed Article $82^{15}$ by refusing to disclose information relative to "specifications for the protocols used by Windows work group servers in order to provide file, print, group and user administration services to Windows work group networks". ${ }^{16}$ Microsoft's strategy allegedly consisted in preserving privileged connections between its client PC operating system and its work group servers, in order to retain a comparative advantage over rivals employing a different technology with respect to client-to-

\footnotetext{
${ }^{12}$ The Commission's decision is currently under judicial revision. The President of the Court of First Instance in his order on the interim measures found that it was for the Court dealing with the substance of the case to decide if "a manifest error was made in the evaluation of the interests involved, in particular in connection with the protection of the intellectual property rights relied on and the requirements of free competition enshrined in the EC Treaty", Case T-201/04 R, at para. 224.

${ }^{13}$ See G.Badal, M.J.Lawrence, From Magill to Microsoft: Is the European Union's Insistence on Compulsory Licensing of Intellectual Property Rights a Threat to Innovation, American Bar Association, Intellectual Property Committee, Fall 2004, 42, at 51 et seq. ; F.Lévêque, Innovation, Leveraging and Essential Facilities: Interoperability Licensing in the EU Microsoft Case, 28 W.Comp (2005), 71; D.Gerardin, Limiting the Scope of Article 82 of the EC Treaty: What can the EU learn from the U.S. Supreme Court's Judgment in Trinko in the wake of Microsoft, IMS, and Deutshe Telekom?, in CMLR (2004), 1519; D. Ridyard, Compulsory Access under EC Competition Law - A New Doctrine of "Convenient Facilities" and the Case for Price Regulation", European Competition Law Review (2004), 669.

${ }^{14}$ Lévêque, as note 13 above, at 79: "The simplification made by the Commission to facilitate the demonstration of the incentives test is not robust. It is not therefore certain that Microsoft passes the new test of incentives balance". See also infra, Sections 4 and 5.

${ }^{15}$ The other way in which Microsoft had committed an abuse of a dominant position was by tying of Windows Media Player with the Windows operating system.

${ }^{16}$ Microsoft, as note 8 above, para. 546 .
} 
server and server-to-server ${ }^{17}$ interoperability. Such privileged connections are related to the main tasks normally performed by work group servers, such as group and user administration services (e.g. directory services, security and authentication services, etc.) and file and print services. Since both server-to server and client-to-server interoperability are key ingredients for the successful marketing of a server system, the advantages of Microsoft's products on the downstream market were not only due to objective superiority on the merits, but to a great extent they depended on the feeble interoperability. ${ }^{18}$ The Commission considered this an unfair handicap that, over time, would have eliminated competition on the work group server market in favour of Microsoft's products. By way of remedy, the Commission required Microsoft to divulge all necessary interface information to allow non-Microsoft workgroup server operating system to achieve full interoperability with Windows PCs and Microsoft workgroup servers. To the extent that the interface information at issue covered intellectual property rights, Microsoft was required to conclude licences on reasonable and non discriminatory conditions.

A main issue in the Microsoft case therefore pertains to the refusal to supply interoperability information to one's competitors. As long as the relevant information is covered by copyright, patents and other forms of intellectual property, Microsoft'a abuse more precisely consists in the refusal to license it. As it is well known, under EU competition law a dominant undertaking is not under a general duty to assist its competitors. However, under certain circumstances, an assistance denial by a dominant firm can be considered illegal. This is in particular the case when the dominant firm, by its refusal to supply, seeks to eliminate competition by foreclosing rivals. Perhaps unsurprisingly, the actual identification of the "exceptional" circumstances in which a refusal to supply should be considered abusive has aroused much controversy, and even more so when intellectual property rights are involved. ${ }^{19}$ From the body of EU case law emerges at times the temptation to cut this difficult knot by circumscribing once and for all the relevant circumstances which should be sought for in actual cases ("exhaustive" checklist of exceptional circumstances) ${ }^{20}$ More appropriately, the relevant legal and economic test should provide both for general filters and and a certain degree of flexibility. ${ }^{21}$ This, it seems, is also the way by which the Commission has framed its competitive assessment of Microsoft's unilateral refusal to supply. Accordingly, the EU competition authority applies an "entirety of the circumstances" test by which infringement

\footnotetext{
${ }^{17}$ The server-to-server interoperability is important whenever networks rest on more than one server.

${ }^{18}$ Microsoft, as note 8 above, para. 1064.

${ }^{19}$ The call for a stricter legal test when intellectual property rights are involved has been formulated on various grounds, see C.Humpe and C.Ritter, Refusal to Deal, Global Competition Law Centre Research Papers on Article 82 EC - July 2005, at 142 et seq., for a comprehensive summary of the more relevant arguments and their careful refutal.

${ }^{20}$ A (mostly critical) reading of the IMS Health judgement (as note 7 above) along these lines has been suggested in a number of comments, see e.g. A.Heinemann, Compulsory Licences and Product Integration in European Competition Law - Assessment of the European Commission's Microsoft Decision, International Review of Intellectual property and Competition Law - IIC (2005), 63, at 70 et seq.

${ }^{21}$ How much flexibility a competition rule should optimally allow for (from an economic perspective) has recently become a much debated issue in the law and economics literature, see e.g. D.S.Evans and A.J.Padilla, Excessive Prices: Using Economics to Define Administrable Legal Rules, in 1(1) Competition Policy International (2005), 133 et seq.
} 
must be based on the results of a comprehensive investigation and not be bound by an exhaustive checklist of exceptional circumstances. ${ }^{22}$

Of particular interest here are those parts of the decision in which the Commission deals at length with Microsoft's central claim that the refusal to disclose the requested information was justified given its need to protect valuable intellectual property rights. Despite its ubiquity in EU case law on refusal to supply, the requirement of no objective reasons has so far attracted little attention ${ }^{23}$ and appears under-developed if compared to the other recurring elements of the legal test at issue. ${ }^{24}$ On other occasions the Court of Justice had established that the mere ownership of an intellectual property right would not as such offer a defence of justification for a refusal to license. ${ }^{25}$ However, Microsoft is not merely asserting the exclusive rights to its intellectual property, but points to the circumstance that the requested interoperability information is the result of significant research and development efforts. ${ }^{26}$ The disclosure would prejudice the protection of the outcome of Microsoft's investments in software features, functions and technologies. In other words, Microsoft argues that it was justified in refusing to supply on the grounds that it would eliminate its incentives to innovate. $^{27}$

In order to dismiss Microsoft's claim of objectively justified refusal to supply, the Commission applies a newly framed incentives trade-off test. The balancing exercise at issue requires, first, that the negative impact of the order to supply on Microsoft's incentives to innovate is assessed and, second, that the possible negative effect is weighted off against the positive impact of the order to supply on the entire industry. Only when the positive effects on innovation following on disclosure cannot outweigh the negative impact on the dominant undertaking's incentives to innovate, Microsoft's refusal to supply should be considered justified.

As to the first step of the incentives balancing test, the effects of the obligation to disclosure on Microsoft's incentives to innovate should be assessed "in comparison to the alternative situation where Microsoft's anti-competitive behaviour remains unfettered". ${ }^{28}$ In the latter case, there would be "a serious risk that Microsoft will succeed in eliminating all effective

\footnotetext{
${ }^{22}$ Microsoft, as note 8 above, at para. 555 et seq.

${ }^{23}$ This, however, could be rapidly changing, see for instance P.-J. Loewenthal, The Defence of "Objective Justification" in the Application of Article 82 EC, World Competition (2005), 455 et seq.

${ }^{24}$ Some objective reasons for refusal to supply are indicated in the Notice on the application of the competition

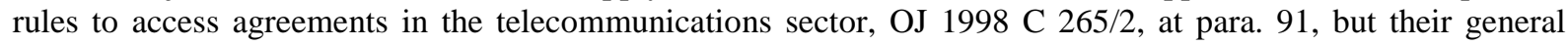
application on other competition issues could be a matter for discussion.

${ }^{25}$ See e.g. Magill, as note 5 above, para. 55. A similar argument ("If intellectual property rights have been lawfully acquired, their subsequent exercise cannot give rise to antitrust liability") was put forth by Microsoft in the US antitrust case brought against its licensing practices in relation to Windows 98 and web browsers, see United States v. Microsoft Corp., 253 F.3d 34 (D.C. Cir. 2001). The Federal Circuit found that the alleged argument bordered upon the frivolous ("The company claims an absolute and unfettered right to use its intellectual property as it wishes: That is no more correct than the proposition that use of one's personal property, such as a baseball bat, cannot give rise to tort liability .... Intellectual property rights do not confer a privilege to violate the antitrust laws.", at 63).

${ }^{26}$ This, for instance, could be an element differentiating Microsoft from Magill since in the latter decision a "research and development" claim could not have been so easily substantiated.

${ }^{27}$ Microsoft, as note 8 above, para. 709 .

${ }^{28}$ Id para. 724 , italics in original.
} 
competition in the work group server operating system market" and this would have "a significant negative effect on its incentives to innovate as regards its client PC and work group server operating system products". ${ }^{29}$ Put differently, incentives to innovate are much likely to vanish if competition is eliminated in the downstream market than if the obligation to disclosure is sustained, because Microsoft would have very little incentive to innovate on that market. Instead, following on from the disclosure obligation, Microsoft's work group server operating system would have to compete with products fully interoperable with the Windows domain architecture and offering new or added functionality. ${ }^{30}$ Microsoft would no longer benefit from a lock-in effect driving consumers towards a homogeneous Microsoft solution, and such competitive pressure would increase Microsoft's own incentives to innovate. Furthermore, because of increased competition on the downstream market, Microsoft would probably feel more competitive pressure also on the upstream market. As the Commission puts it, "Microsoft's research and development efforts are indeed spurred by the innovative steps its competitors take in the work group server operating system market. Were such competitors to disappear, this would diminish Microsoft's incentives to innovate". 31 Moreover, the Commission takes into consideration the incentives to improve the protocols and by that the co-ordination of complementary products (work group server with client-PC). Even though Microsoft had anticipated the disclosure order, it would not have invested less in trying to achieve the best possible interoperability between its client and server software, because "the value of Microsoft's client PC operating system in the eyes of customer (and their willingness to pay) increases through the availability of complementary interoperable work group server operating systems". ${ }^{32}$

To sum up, according to the Commission Microsoft's incentives to innovate would be strongly reduced if Microsoft were entitled to continue refusing to supply the requested interoperability information. The latter view also implies that a formal trade-off between positive (for the industry) and negative (for the dominant undertaking) incentives on innovation becomes unnecessary. Therefore, in the Microsoft decision the incentives balancing test stops at its first step, without need for further inquiry. ${ }^{33}$ A possible way for Microsoft to show that it has an objective justification for its behaviour could be by demonstrating that its innovation incentives would be negatively affected and the overall level of competition in the industry would not be significantly reduced. Conversely, as soon as the negative effects on competition become substantial, Microsoft's incentives to innovate begin to weaken and are bound to disappear once competition on the market is eliminated. In a nutshell, because of the likely elimination of competition on the downstream market

\footnotetext{
${ }^{29}$ Id. para. 725.

${ }^{30}$ Without the interoperability information Microsoft's competitors were not capable of capturing the benefits of their innovation in workgroup server operating systems because compatibility with Windows was the product characteristic users valued most.

${ }^{31}$ Id. para. 725.

${ }^{32}$ Id. para. 726-727.

${ }^{33}$ See also Lévêque, as note 14 above, at 79: "The demonstration [that the increase in industry incentives is not offset by the decrease in the dominant undertaking's incentives, $S$. $V$.] is obviously simplified where compulsory licensing does not diminish firm A's [the dominant undertaking's, $S$. V.] incentives".
} 
following the refusal to supply, Microsoft cannot claim that the justification of its behaviour lies in the need to safeguard its incentives to innovate.

Put in these terms, the result of the incentives balancing test and therefore the holding of an objective justification to supply would ultimately depend on how competition on the downward market affects the dominant undertaking's incentives to innovate. If the elimination of downstream competition does not affect the dominant undertaking's need to innovate, this undertaking could (still) claim that the refusal to supply is justified by the need to safeguard its incentives to do so. Conversely, a "research and development incentives" defence would hardly be sustainable if the refusal to supply had the effect to restrict competition on the downstream market and thereby to substantially limit the dominant undertaking's incentives to innovate.

\section{A Feaseble and Useful Test?}

At first glance, the newly introduced incentives balancing test has the merit to touch on the core of the controversial debate at the intersection between intellectual property and competition law. If, according to economic theory intellectual property rights are foreseen as incentives in order to spur innovation, they should hardly be sustainable whenever it can be proved that they actually induce the opposite effect of hindering innovation. Indeed, in the last decade economic thinking has moved quite a long way from its early almost deferential attitude vis-a-vis intellectual property rights. A considerable amount of research efforts have been devoted to understanding when exclusive rights to intellectual property may be expected to foster innovation and when the opposite case is more likely. Thus, for instance, it has been suggested that a regime strongly supporting the exclusive rights of inventors could induce undertakings to protect with patents also unused technologies and by that hinder the exploration of specific technological trajectories by competitors. ${ }^{34}$ Moreover, the increased costs of litigation because of the proliferation of intellectual property protection could negatively effect incentives to innovate, especially by small firms. ${ }^{35}$ Finally, when innovations are complementary, it could be proved that intellectual property rights often constitute a deterrent for investment in innovation. ${ }^{36}$ The Microsoft case can help elucidate the latter point. A complementary relationship exists between interoperability information and workgroup server software, so that it could be affirmed that if undertakings cannot get

\footnotetext{
${ }^{34}$ W.M.Cohen, R.R.Nelson, J.P.Walsh, Protecting Their Intellectual Assets: Appropriability Conditions and Why U.S. Manufacturing Firms Patent (or Not), National Bureau of Economic Research Working Paper No. 7552. (2000).

${ }^{35}$ For empirical evidence supporting this conclusion see J.O. Lanjouw and J.Lerner, Tilting the Table? The Predatory Use of Preliminary Injunctions, in 44(2) Journal of Law and Economics (2001), 573 and J.O. Lanjouw and M. Schankerman, An Empirical Analysis of the Enforcement of Patent Rights in the United States, in Cohen W. and Merrill S. (eds.), Patents in the Knowledge-Based Economy (2003), National Academy Press: Washington, D.C.

${ }^{36}$ Heller M., Eisenberg R., Can Patents Deter Innovation? The Anticommons in Biomedical Research, Science 280, 5364 (1998), 698 et seq. For empirical evidence suggesting that this so-called "anti-commons" problem may be less serious than predicted see W.M.Cohen, A.Arora, J.P. Walsh, Effects of research tool patenting and licensing on biomedical innovation, in Merrill. and Cohen, as note 35 above.
} 
access to innovation 1 (interoperability information), they cannot make innovation 2 (advanced features of workgroup server software). ${ }^{37}$ Put differently, because of the exclusive rights on interoperability information, firms on the work group server software market are refrained from investing in the innovation of the product's characteristics.

Under this light, the Microsoft incentives balance test would seem to be in line with the most recent economic thinking on intellectual property rights. The Commission's newly introduced test for the objective justification of a refusal to license could move our attention to identifying the special circumstances in which intellectual property rights do not fulfil the function for which they are granted. Because of its exclusive focus on innovation incentives, the newly introduced test is also notably different from other balancing exercises previously suggested in similar contexts. For example, the D.C. Circuit in the U.S. Microsoft en banc decision affirmed in obiter dicta that a monopolization claim could be sustained if "the anticompetitive harm of the conduct outweighs the procompetitive benefit". ${ }^{38}$ Indeed, from a pure ex post perspective, refusal to deal could constrain consumer choice, lower input, raise prices, and thereby producing allocative inefficiency. According to this test, competition authorities and tribunals should therefore be required to engage in a social welfare calculus whether the social value of the improvement (a "better" product) offsets the inefficiency produced by the loss of competition (short term - static- harm to consumers balanced against the expected long term - dynamic - benefits to consumers). This turns to a test by which the refusal to supply should be condemned when by doing so social welfare is enhanced. The above mentioned social welfare calculus is however very controversial, and its feasibility "in any predictable or useful way" has been seriously questioned. ${ }^{39}$

Notwithstanding the possible support of the incentives trade-off test from the more recent economic theories on intellectual property and its qualitative difference from other balancing exercises, in the following it is submitted that the Microsoft legal test for the objective justification of refusal to license raises some major difficulties especially ${ }^{40}$ when considered against the background of our still limited, albeit growing knowledge ${ }^{41}$ about the working of innovation processes.

\section{More innovation on the work group server software market?}

It has become increasingly apparent that innovation can come from very unlikely sources and that the incentive mechanisms spurring it may be significantly different from traditional property rights. The open source software ${ }^{42}$ movement gives an intriguing example of an alternative way to organise innovation. There we have individuals developing and exchanging

\footnotetext{
${ }^{37}$ Lévêque, as note 14 above, at 78 et seq. See also Microsoft, as note 8 above, at para. 695 .

${ }^{38}$ United States v. Microsoft Corp., 253 F.3d 34, 55 (C.A.D.C. Cir. 2001).

39 See Humpe and Ritter, as note 19 above, at 149; and E.Elhauge, Defining Better Monopolization Standards, in 56 Stanford Law Review (2003), 253, at 319. See also Loewenthal, as note 23 above, at 470.

${ }^{40}$ For other critical comments see the studies cited in note 13 above.

${ }^{41}$ Reference is particularly made to the fast developing research area on the economics of innovation.

${ }^{42}$ A software product is said to be "open source" when its source code is made freely available to the customer, who may copy, modify and distribute it under certain conditions.
} 
software without any apparent gain in terms of direct monetary reward. A considerable amount of research efforts have been recently devoted to understand the individuals' (programmers') motivations ${ }^{43}$, the way open source projects are organized ${ }^{44}$ and the competitive dynamics between proprietary (closed) and open software development systems. ${ }^{45}$ Moreover, it is observed that firms now play an important role in the development of open source, possibly holding motivations to some extent different from those of individuals. ${ }^{46}$ The open source software movement has attracted attention also in the context of the Microsoft decision. ${ }^{47}$ Work group operating system products based on an open source code detained a large share of the market, which however started decreasing when Microsoft made its appearance with its category of concurring products.

In this respect, it is not at all clear whether by mandating access to interoperability information, innovation on the work group server market will increase in any substantial way. In fact, it is not easy to predict what the likely impact of compulsory licensing on the innovation incentives is going to be. According to the Commission, thanks to mandated access to interoperability information work group software producers should be expected to invest more in the innovation of their products. ${ }^{48}$ The reasoning seems plausible if it is considered that those producers, due to non-disclosure, could not capture the benefits of their innovations. ${ }^{49}$ However, there are two main difficulties with this argument. The first one is that it is not disputed that considerable investments in group work server software were made also before the disclosure order was issued; second, that the traditional reward appropriability by way of exclusive rights on product innovations is not what motivates some of Microsoft's most fierce competitors on the work group operating system market. ${ }^{50}$

Possibly, resources that Microsoft's competitors on the downstream market previously devoted to reverse engineering ${ }^{51}$ will now be employed for the development of new product characteristics, thus fostering innovation. This reasoning should however be careful to avoid the (still common) fallacy of considering the innovation performance of a specific firm as the

\footnotetext{
${ }^{43}$ See e.g. E. von Hippel, Democratizing innovation, MIT Press, 2005; C.Baldwin \& K.Clark, The architecture of cooperation : Does code architecture mitigate free riding in the open source development model ?, Harvard Business School Working Paper Series (2004). For a survey see M.A. Rossi, Decoding the "Free/Open Source (F/OSS) software puzzle" a survey of theoretical and empirical contributions. Working paper n. 424, Siena University.

${ }^{44}$ See e.g. K.Edwards, An economic perspective on software licences-open source, maintainers and userdevelopers, 22 Telematics and Informatics (2005), 111.

${ }^{45}$ The question this part of the literature focuses on is whether the open source software movement (assuming that programming is accomplished by volunteer programmers) can ultimately defeat Microsoft in the marketplace, see for a formal economic model P. Ghemawat and R.Casadesus-Masanell, Dynamic Mixed Duopoly: A Model Motivated by Linux vs. Windows, Harvard Business School, Working Paper No. 04-012.

${ }^{46}$ A.Bonaccorsi, and C. Rossi, Altruistic individuals, selfish firms? The structure of motivation in Open Source software, 9(1) First Monday, 2004.

${ }^{47}$ Microsoft, as note 8 above, especially at paras. 26-29; 101-106; 293-297.

${ }^{48}$ Microsoft, as note 8 above, para. 695;

${ }^{49}$ Lévêque, as note 14 above, at 78 . See also note 30 above.

${ }^{50}$ If those competitors had adopted a business model based on proprietary software, however, more incentives to produce innovation because of access to interoperability could have been possibly expected.

${ }^{51}$ See Microsoft, as note 8 above, paras. 292 for a detailed examination of those efforts.
} 
direct result of its expenses in research and development. ${ }^{52}$ As more recent studies on the economics of innovation have shown, innovation is a much more complex phenomenon, involving inter alia diversified knowledge bases and specific capacities (e.g. "absorptive capacity") by economic actors, path dependencies of technological developments and unpredictable events. ${ }^{53}$ Moreover, it should be recalled that given the complementarity between the products that form a complex system like a PC, the ability of downstream competitors to bring product innovations to market is already heavily restricted. In fact, those more relevant changes in group work server software that would require modifications to Windows client operation system are very unlikely to be implemented if they stem from Microsoft's competitors, whereas, if the innovation comes from the latter's own downstream arm, the necessary modifications are probably implemented at once.

It also seems clear that innovation on the work group software market will critically depend on the actual conditions of the disclosure obligation. The remedy requires Microsoft to share details of the technologies used by its server products to communicate with Windows clients: independent software developers should be able to build products that communicate and fully interoperate with Windows-based PCs. The information must be comparable to that disclosed by Microsoft to its own employees and contractors developing Microsoft's own work group server. However, innovation on software products for work group servers can be expected to be much less effective if some important actors, like open source software projects, are practically prevented from taking part in the Microsoft's licensing program. ${ }^{54}$

To sum up, on first consideration it appears likely that more competitive innovation can be expected on the work group server software market thanks to the disclosure obligation. It is submitted, however, that the innovation dynamics on the work group server market and the actual conditions of the disclosure licensing program should have deserved a more careful analysis before the remedy phase of the case. Admittedly, in view of our still limited knowledge about the nature and the working of innovation processes, a readily formulated answer to this question should not be expected.

\section{More innovation in the entire industry?}

Interestingly, competition policy interventions are often scarcely effective in the PC industry. ${ }^{55}$ Economic studies have shown that this particular economic sector tends to have

\footnotetext{
${ }^{52}$ This problem goes all of the way back to the "incentives based" innovation studies, see A.Pyka, Der kollektive Innovationsprozeß, Berlin: Duncker \& Humblot, 1999, at 83.

${ }^{53}$ In the last twenty years the literature on the economics of innovation has been developing at rapid pace. For an introduction see e.g. G.Dosi, , C.Freeman, , R.Nelson, , G.Silverberg, and L. G.Soete, (eds.), Technical Change and Economic Theory, 1988, London: Pinter; Von Hippel, E., The Sources of Innovation, 1988, New York: Oxford University Press.; J. S. Metcalfe, Evolutionary Economics and Creative Destruction, (1998), London: Routledge.

${ }^{54}$ This is matter of acute dispute in the implementation phase of the Microsoft decision, see the Statement issued by the Commission on March 18, 2005 and its following press release of June, 6. On this issue, the advice of the newly (October, 5) appointed Monitoring Trustee will possibly play a decisive role.

${ }^{55}$ For a critical assessment of the competition remedies in the U.S. Microsoft case see in particular T.Bresnahan, A Remedy that Falls Short of Restoring Competition, in Antitrust (2001), 67 et seq. The U.S. IBM case was
} 
both more forces for change (Schumpeterian competition ${ }^{56}$ or competition for markets) and more forces for stasis (e.g. network effects ${ }^{57}$ ) at work than other industries. ${ }^{58}$ It is against the background of these peculiar characteristics that the Commission's claim of more innovation for the entire industry thanks to disclosure of interoperability information should be assessed. The Commission supports a view according to which a competitive undertaking is better placed to innovate than a monopolist. ${ }^{59}$ As it is well known, this is still a very controversial issue from the economic perspective. ${ }^{60}$ In this respect, the history of the economic sector at issue could become a source of valuable insights. ${ }^{61}$ Indeed, the argument that innovation is best supported and financed by firms with significant monopoly power would seem to find little support in industries like the PC. Innovation in Schumpeterian terms has invariably come from undertakings challenging the incumbent dominant position. ${ }^{62}$ But what the history of the industry also tells us is that an innovative idea has hardly proved sufficient to enter the market and enable the wave of creative destruction. Because of network effects and other stasis forces at work, some additional conditions had to be fulfilled. In particular, changes in complementors $^{63}$ were necessary to bring in a considerable number of users with characteristics that were at least to some extent different from existing users. ${ }^{64}$ In fact, network effects are bound to devalue if new users are attracted to the industry and these users have demand characteristics different from existing users. In other words, changes, innovation by complementors have lowered entry barriers and created new opportunities for substitute products to compete for the market. Insofar, it seems that less control of other layers by the incumbent dominant undertaking and more desintegration in the industry would be important ingredients in order to foster innovation in the PC industry. Not only, therefore, a decentralized industry can be more innovative at each of the layers composing it; a decentralized system can also lead to a more extreme form of innovation, namely Schumpeterian creative destruction.

hardly more successful, see F.M.Scherer, Technological Innovation and Monopolization, American Antitrust Institute Working Paper 05-07 (2005), 47 et seq.

${ }^{56}$ T.Bresnahan, Creative Destruction in the PC Industry, Paper presented to the Conference on IT Innovation, Tokyo, December 2004, available at http://www.iir.hit-u.ac.jp/file/WP05-03bresnahan.pdf (last checked November 2005).

${ }^{57}$ See S.M. Besen and J.Farrell, Choosing How to Compete: Strategies and Tactics in Standardization, in 8(2) Journal of Economic Perspectives (1984), at 117 et seq.

${ }^{58}$ See P.A.Geroski, Competition in Markets and Competition for Markets, in Journal of Industry, Competition and Trade, 151, at 153. Some authors, however, dispute the importance of network effects in the software industry, see e.g. R.Schmalensee, Antitrust Issues in Schumpeterian Industries, 90(2) American Economic Review, American Economic Association (2000), at 192: "Contrary to the simple network industry models, switching costs and lock-in do not appear to be important in the case of software. Major innovations occur repeatedly, and category leaders are frequently displaced by better products".

${ }^{59}$ See Section 2 above.

${ }^{60}$ In the context of the Microsoft decision see e.g. Lévêque, as note 14 above, at 79.

${ }^{61}$ Throughout this part of Section 4, I draw heavily on Bresnahan, Creative Destruction in the PC Industry, as note 56 above, at 5 et seq.

${ }^{62}$ From the beginning of the PC industry in 1975 we have experienced successive ways of creative destruction, e.g. IBM PC replacing Apples and CP/M; Microsoft replacing IBM PC.

${ }^{63}$ E.g., spreadsheet (VisiCalc) and word processing program (WordStar) for the first wave surrounding the introduction of the IBM PC.

${ }^{64}$ For instance, white collar workers in corporations enabling the first wave. 
A recent occasion for those favourable conditions for Schumpeterian innovation to materialize occurred when the Internet became broadly used. An innovative browser (Netscape) attracted many new PC users (home, multimedia, communication users) and was followed by a large class of new applications. However, as it is well known from the U.S. Microsoft case, the wave of creative destruction never started rolling. Microsoft engaged in specific actions with the aim of blocking the widespread distribution of the Netscape browser and prevented thirdparty complementors from working with Netscape. ${ }^{65}$

Certainly, the disclosure obligation of interoperability information, if properly implemented, could help reestablishing at least some of the vertical desintegration that characterized the first 20 years of the PC industry. As a consequence, the entire industry, Microsoft included, could experience a certain degree of increased innovation incentives, however, of course, not comparable to those induced by an actual threat of creative destruction. What the history of this particular industry could in particular tell us is that, in order to have more serious chances of Schumpeterian innovation, other, stricter competition remedies should possibly have been envisaged. $^{66}$

\section{Conclusions}

The incentives balance test has been employed by the Commission in order to dismiss Microsoft's claim that the disclosure of interoperability information would have reduced its incentives to innovate. The Commission's reasoning on this point involves at least two logical steps. Following from disclosure of interoperability information there would be more competition in the industry; thanks to more competition, more (and not less) incentives to innovate should be expected. As it stands, this newly framed trade-off is highly controversial and there are also serious doubts that, when applied to the circumstances of the case at issue, the result could indeed help supporting the Commission's finding of abusive conduct under 82 of the EC Treaty on the part of Microsoft.

In spite of all well-founded criticism, the main aim of this paper was to show that a mindful discussion of this test should be on the agenda of the expected policy debate on a more "economics-based" approach to Article 82. If nothing else, the implementation of this balancing exercise in the context of the Microsoft decision has raised a number of issues that should deserve careful examination in the context of a pro-innovation competition policy. Thus, it is apparent that we still know comparatively little about the nature and the working of innovation processes. In particular, too little efforts have so far been devoted to understanding

\footnotetext{
${ }^{65}$ As it became clear also in the U.S. Microsoft case, control over interaction information is a very powerful market tool and Microsoft does not hesitate to use it whenever it suits its business objectives. For instance, Microsoft used its control of interface information to compler third-party complementors not to work with Netscape, see Bresnahan, Creative Destruction in the PC Industry, as note 56 above, at 22. May be, by refusing to supply interoperability information to Sun and other competitors, Microsoft not only was trying to reserve to itself the work group software market, but was also anticipating future competitive threats of a much larger impact on its incumbent super-dominant position.

${ }^{66}$ The question of the right remedies increasingly profiles itself as one of the most relevant issues for competition policy, see e.g. the Comments of the American Antitrust Institute Working Group on Remedies, as recently filed to the Antitrust Modernization Commission (document available at http://www.amc.gov/public_studies_fr28902/remedies_pdf/AAI_Remedies.pdf, last checked November, 2005).
} 
spontaneous ways of innovation organization, as for instance the open source software movement, or to clarifying the mutual influences amongst innovation processes at different industry layers. Moreover, the framing of remedies in industries characterized by Schumpeterian modes of innovation would seem to require additional thinking. Of course, most of the questions briefly summarized above pose significant challenges, and we cannot reasonably expect a competition policy podium to be the most suitable context to face them. Nevertheless, a pro-innovation "economics-based ${ }^{67 "}$ " competition policy cannot avoid taking into account that much less certainty and hard facts can be expected, at this stage, even from the most modern and accurate economic theories and methods than would be advisable for rational, predictable and effective competition intervention. ${ }^{68}$

\footnotetext{
${ }^{67}$ Especially if by "more economic" it is meant an "effects-based" approach employing empirical methods of analysis in individual cases.

${ }^{68}$ For an approach explicitly incorporating uncertainty into competition decision making and remedies, see K.Heyer, A World of Uncertainty: Economics and the Globalisation of Antitrust, 72(2) Antitrust Law Journal (2005), at 375 et seq.
} 